DOI: $10.2478 /$ ace-2013-0017

\title{
IMPACT OF BASELINE TERMS ON THE COURSE OF CRITICAL PATHS AND TIME BUFFERS IN THE MODIFIED GOLDRATT'S METHOD
}

\begin{abstract}
M. POŁOŃSKI ${ }^{1}, K$. PRUSZYŃSKI ${ }^{1}$
The introduction of a baseline term to the dependency network most often results in a change, break and/or generation of a new sequence of critical path, depending on the type of such a baseline term and the exact date selected. Each of those situations has an impact on the location or need to include new time buffers in the modified Goldratt's method. The purpose of this article was to identify possible effects brought by declaration of each type of baseline term and to point out actions to be taken in each case. It must be noted that guidelines provided should in each individual case be adapted to the specific character of schedule changes caused by implementation of the relevant baseline term.

The example presented herein exemplifies one of such solutions to be implemented as a result of break of the critical path and need to introduce new time buffers.
\end{abstract}

Key words: project buffer, baseline term, critical path, Goldratt's method

\section{INTRODUCTION}

In engineering practice, various types of constraints (so-called baseline terms) are often used. Sometimes they need to be used for technological and organizational reasons, while in other cases - because it is necessary to meet a contractual deadline for completion of a stage or the whole construction task. Proper implementation of appropriate constraints during scheduling of civil works can contribute to efficient management of construction project execution [3,7].

The categories of different types of constraints which can be used in schedules are borrowed from C. Chatfield and T. Johnson [1] and from S. Wilczewski [8], who split those constraints into three groups: flexible, inflexible and moderate (semi-flexible). Such classification also applies to baseline terms which can be used in MS Project, applied herein for the purpose of schedule analysis. Similar constraints can also be found in other project management software tools (Primavera, PertMaster). To select and implement a specific type of the aforementioned constraints, it is necessary to define an appropriate type of constraint and to determine its date. Types of constraints which can be used in MS Project are described below in order of appearance in the system.

1 Division of Technologies and Organization of Engineering Works, Warsaw University of Life Sciences. e-mail: mieczyslaw_polonski@sggw.pl 
The first group includes flexible constraints which, whenever used, enable the system to determine the start and finish date of a given task. Every task which is subject to this constraint shall be planned in such a way as to be completed as late (constraint type „As Late As Possible”) or as soon (constraint type „As Soon As Possible”) as it can be completed. In this type of constraint no date needs to be provided.

The second group contains inflexible constraints. Any task under such a constraint, or, to be more specific, its start or finish, according to the selected option, shall occur on a strictly determined date. The system shall calculate the time frame for task execution in such a way as to make it start (constraint type „Must Start On”) or finish (constraint type „Must Finish On”) exactly on the selected date.

The third group is constituted by moderate (semi-flexible) constraints. They are a kind of barrier for free planning because they reduce the number of possible changes in start and finish dates selected for specific tasks. Nevertheless, such a limitation guarantees that a given task will not start after a determined date (constraint type "Start No Later Than") or before a determined date (constraint type „Start No Earlier Than”) or that a given task will not be finished after a determined date (constraint type „Finish No Later Than”) or before it (constraint type „Finish No Earlier Than”).

The system's default type of constraint for any task scheduled is "As Soon As Possible".

To meet a deadline likely to be jeopardized during execution of a construction project, either „Must Start On” (inflexible) or „Start No Later Than” constraint (moderate) is most often used, depending to the specific needs of each case [3]. It depends, however, on the needs defined by the scheduler each time a schedule is developed. Emphasis must be placed on the responsibility incumbent on the engineer who develops a given schedule. They ought to consider and take into account necessary technological and organizational assumptions underlying the construction task under preparation, yet, first and foremost, they should be aware that if they use baseline terms in a wrong way, they can lose control over the schedule because such baseline terms can contradict one another.

Therefore, it is recommended to start scheduling by building a dependency network and analyzing the earliest deadlines (organizational reasons). Then, technological needs must be taken into consideration, because their impact often makes it necessary to use a specific type of constraints. As a result, subsequent time analyses along with tracking down and evaluation of impact of successively introduced baseline terms on the final deadline and course of the critical path creates desired effects. Hence, baseline terms must be used in a very skillful and thought-out way.

While applying constraints to a schedule, especially inflexible ones, one should bear in mind that their use can, apart from the aforementioned aspects, lead to a change and/ or break of the critical path. It is, however, closely related to the date determined for the constraint and the selected type of constraints. The latest baseline terms (inflexible and moderate ones) can also result in occurrence of a negative total slack which, in turn, can lead to selecting unrealistic lead times for tasks. Nevertheless, it is also important to 
assign the earliest deadlines to those tasks which can extend the duration of the whole project.

\section{METHOD}

To use baseline terms, you must be aware of the consequences they are likely to bring for the schedule. Types of effects to the slack and course of the critical path depend on the selected types of constraints and adopted baseline dates, which, in turn, often decide whether it is necessary to modify the location of time buffers used in the Goldratt's method $[2,4,5]$. Figure 1 shows a diagram which identifies possible consequences of implementation of a task's baseline term in the dependency network .

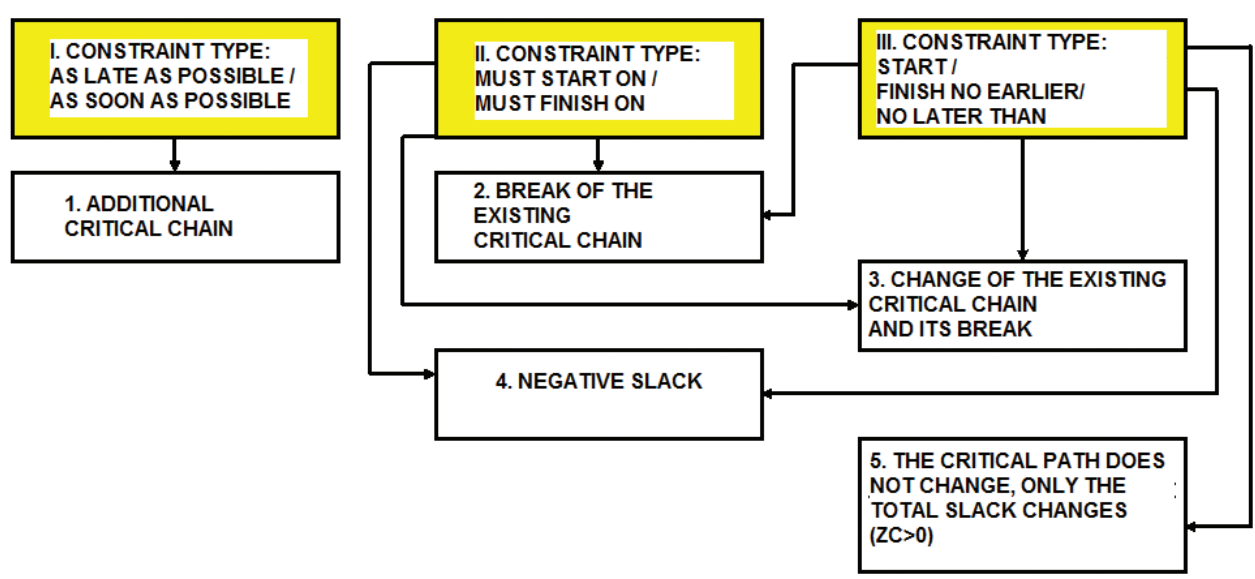

Fig. 1. Diagram of types of constraints with possible consequences of their implementation

I. Constraint type: "As Late As Possible / As Soon As Possible"

1. Additional critical chain

II. Constraint type : "Must Start On / Must Finish On"

2. Break of the existing critical chain

3. Change of the existing critical chain and its break

4. Negative slack

III. Constraint type: "Start / Finish No Earlier / No Later Than

5. The critical path does not change, only the total slack changes.

Whenever any of possible consequences occurs, it is necessary to take the appropriate action in the modified Goldratt's method (as shown in Figure 1):

1. to implement new buffers, as for the existing critical sequences, 
2. to use a feeding buffer at the end of the non-critical sequence which has arisen (just before the task with a baseline term), and if needed, to add buffers wherever new non-critical sequences part their ways,

3. to implement appropriate time buffers once again in the new location,

4. to change dates and/or types of baseline term so as to avoid negative slack,

5. to leave designed time buffers as they are,

\section{Calculation example}

This example is based on the schedule of earth works developed for construction of the „A19” metro station in Warsaw (Figure 2). These data were adopted as an output model for further stages of the experiment the purpose of which is to depict an exemplary impact of a baseline term on the course of a critical path (critical chain) in the event time buffers are implemented.

The initial deadline scheduled for the whole project is 09 August 2005, with the duration being 83 days.

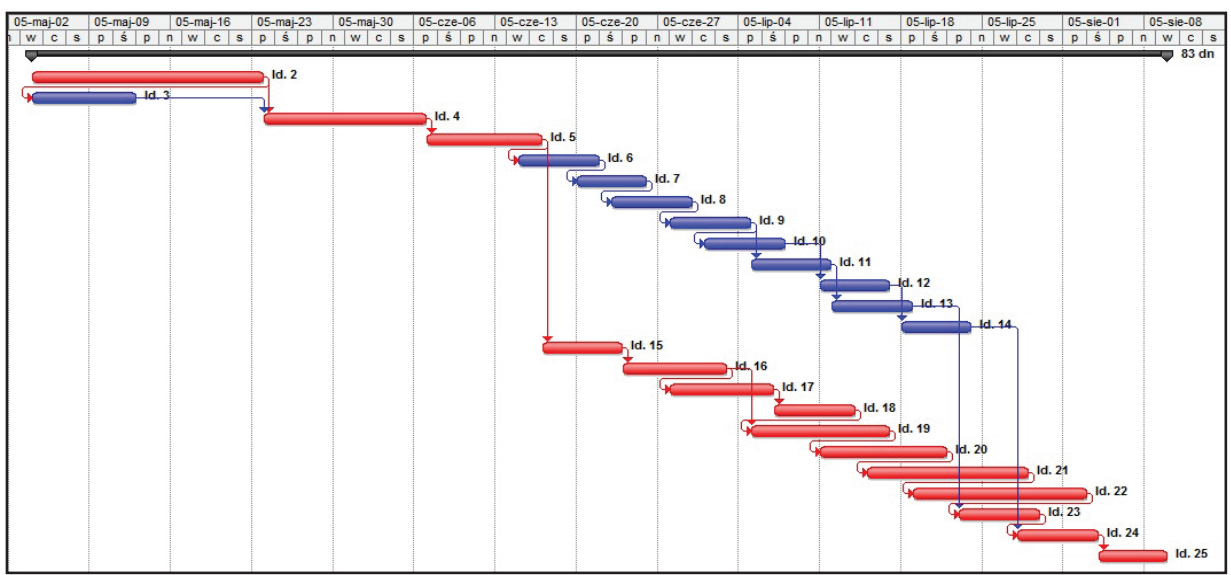

Fig. 2. Schedule of earth works developed for construction of the „A19” metro station with no baseline date being fixed (tasks belonging to the critical path are marked in red)

The baseline term - inflexible „Must Start On” constraint was assigned to the task no. 18 , lying on the critical path. The initial start date for this task is 07 July 2005 , but the selected constraint puts the start off until 18 July 2005. Once the constraint has been implemented, the finish date for the whole project becomes 20 August 2005, while the project execution takes 92 days.

As a result of the adopted baseline term, the critical path was broken (case no. 2, figure 1). As the course of the critical path changed, it was necessary to add a new 
feeding buffer - BZ1 and BRN1[4] where non-critical sequences part their ways (see figure 3 and 4).

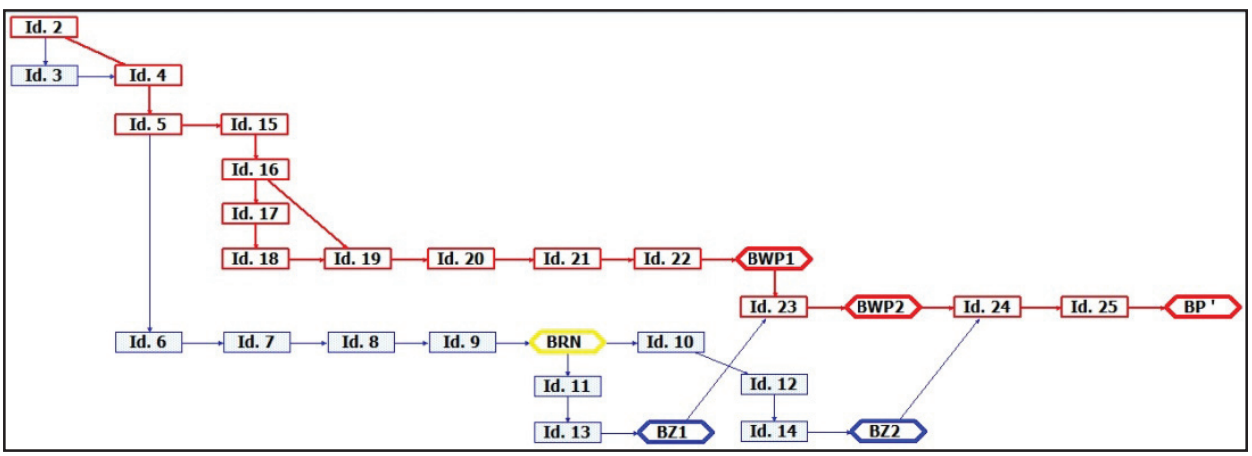

Fig. 3. Dependency network with time buffers without implementation of the baseline term

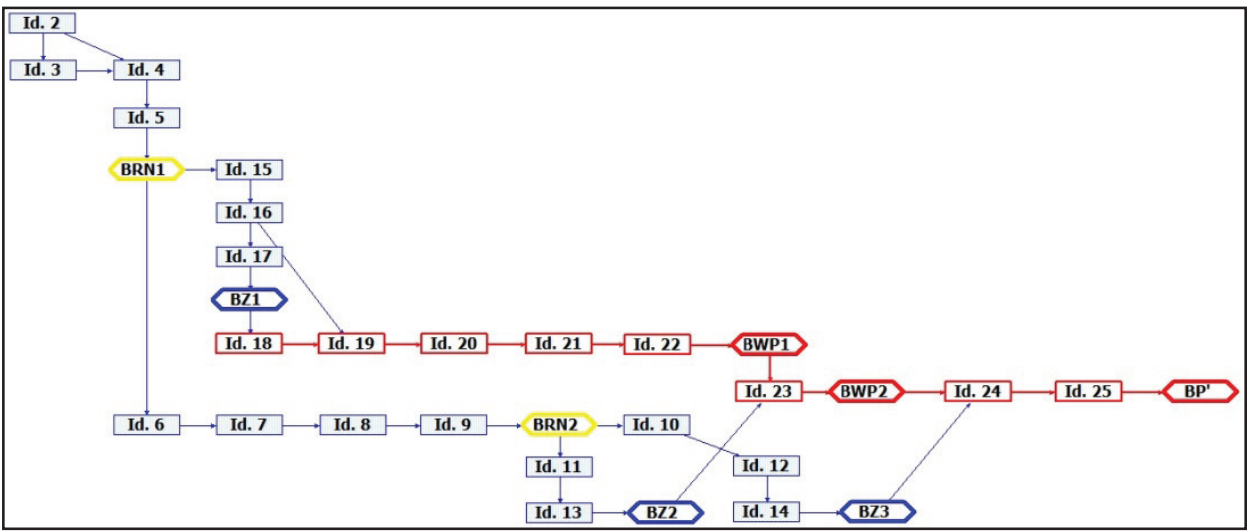

Fig. 4. Dependency network with inserted time buffers BZ1 and BRN1 after implementation of baseline term

The schedule obtained after the implementation of the baseline term can be seen in Figure 5.

To calculate the buffer size, the duration of all the tasks included in the dependency network was reduced. To make the calculations easier to comprehend, the duration of the tasks was reduced in \% and appropriate relations were shown in the schedule model. It resulted in the following sizes of applied time buffers [4,5] (table 1). 


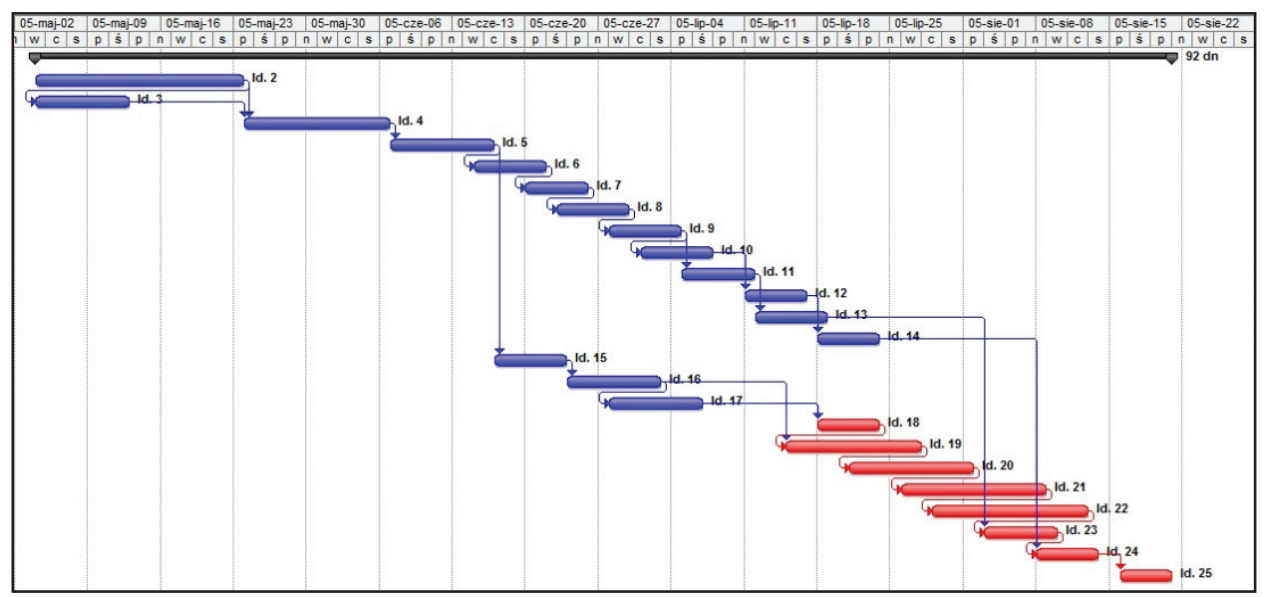

Fig. 5. Gantt chart with the „Must Start On 18 July 2005” baseline date assigned to the task no. 18 (tasks lying on the critical path are marked in red)

By inserting the calculated time buffers to the dependency network, the schedule was obtained as shown in Figure 6 and Table 2.

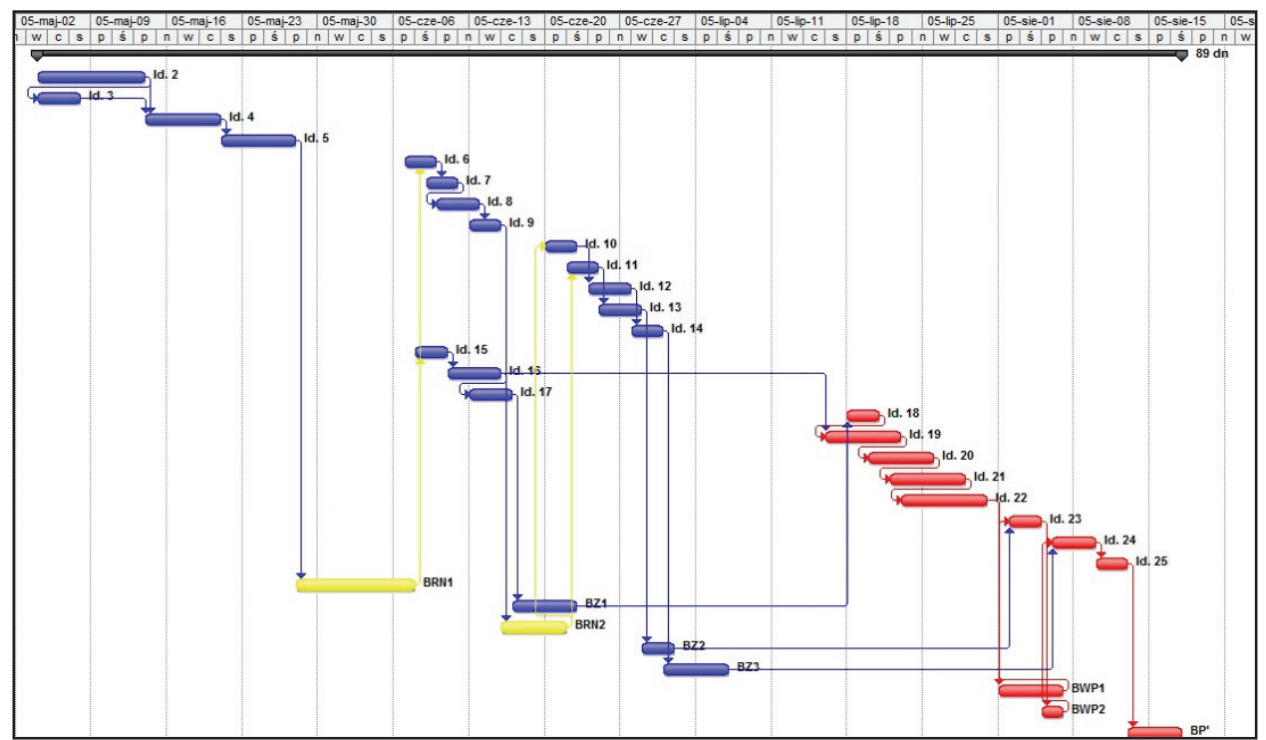

Fig. 6. Gantt chart with the baseline term after insertion of time buffers (shown with their sizes) (tasks lying on the critical path are marked in red). 
Table 1

Table showing sizes of adopted time buffers

\begin{tabular}{|c|c|c|c|c|c|c|c|c|c|c|c|c|}
\hline \multirow{4}{*}{ Lp. } & \multirow{4}{*}{$\begin{array}{l}\text { Nazwa bufora czasu } \\
\text { wraz z chronionym } \\
\text { przez niego ciągiem } \\
\text { czynności }\end{array}$} & \multirow{3}{*}{\multicolumn{2}{|c|}{$\begin{array}{l}\text { Id. ciągu } \\
\text { czynności }\end{array}$}} & \multicolumn{8}{|c|}{ Termin trwania ciągu czynności } & \multirow{4}{*}{$\begin{array}{c}\text { Obliczony } \\
\text { czas trwania } \\
\text { bufora }\end{array}$} \\
\hline & & & & \multicolumn{4}{|c|}{ Przed skróceniem } & \multicolumn{4}{|c|}{ Po skróceniu } & \\
\hline & & & & \multicolumn{2}{|c|}{\begin{tabular}{c|} 
Rozpoczęcie \\
$\mathrm{Tpp}_{\mathrm{i}}$
\end{tabular}} & \multicolumn{2}{|c|}{$\begin{array}{c}\text { Zakończenie } \\
T_{p k_{j}} \\
\end{array}$} & \multicolumn{2}{|c|}{\begin{tabular}{c|} 
Rozpoczęcie \\
Tsp $_{\mathrm{i}}$
\end{tabular}} & \multicolumn{2}{|c|}{$\begin{array}{c}\text { Zakończenie } \\
\text { Tsk }_{\mathrm{j}} \\
\end{array}$} & \\
\hline & & $\mathbf{i}$ & $\mathbf{j}$ & Data & $\begin{array}{c}\text { Wartość } \\
\text { numeryczna }\end{array}$ & Data & \begin{tabular}{|c|} 
Wartość \\
numeryczna
\end{tabular} & Data & \begin{tabular}{|c|} 
Wartość \\
numeryczna
\end{tabular} & Data & $\begin{array}{c}\text { Wartość } \\
\text { numeryczna }\end{array}$ & \\
\hline 1 & $\begin{array}{l}\text { BRN1 } \\
\text { ciąg Id. 2-3-4-5 }\end{array}$ & 2 & 5 & 04.05 .2005 & 1 & 16.06 .2005 & 37 & 04.05 .2005 & 1 & 27.05 .2005 & 20 & 9 \\
\hline 2 & $\begin{array}{l}\text { BZ } 1 \\
\text { ciąg Id. 15-16-17 }\end{array}$ & 15 & 17 & 17.06 .2005 & 38 & 06.07 .2005 & 54 & 28.05 .2005 & 21 & 06.06 .2005 & 28 & 5 \\
\hline 3 & $\begin{array}{l}\text { BRN2 } \\
\text { ciąg Id. 6-7-8-9 }\end{array}$ & 6 & 9 & 15.06 .2005 & 36 & 04.07 .2005 & 52 & 27.05 .2005 & 20 & 04.06 .2005 & 27 & 5 \\
\hline 4 & $\begin{array}{l}\text { BZ2 } \\
\text { ciagg Id. 11-13 }\end{array}$ & 11 & 13 & 05.07 .2005 & 53 & 18.07.2005 & 64 & 06.06 .2005 & 28 & 11.06 .2005 & 33 & 3 \\
\hline 5 & $\begin{array}{l}\text { BZ3 } \\
\text { ciąg Id. 10-12-14 }\end{array}$ & 10 & 14 & 01.07 .2005 & 50 & 23.07 .2005 & 69 & 03.06 .2005 & 26 & 14.06 .2005 & 35 & 5 \\
\hline 6 & $\begin{array}{l}\text { BWP1 } \\
\text { ciagg Id. 18-19-20-21-22 }\end{array}$ & 18 & 22 & 18.07 .2005 & 64 & 12.08 .2005 & 86 & 18.07 .2005 & 64 & 30.07 .2005 & 75 & 6 \\
\hline 7 & $\begin{array}{l}\text { BWP2 } \\
\text { ciag Id. } 23 \\
\end{array}$ & 23 & 23 & 03.08 .2005 & 78 & 09.08 .2005 & 83 & 26.07 .2005 & 71 & 28.07 .2005 & 73 & 2 \\
\hline 8 & $\begin{array}{l}\mathrm{BP}^{\prime} \\
\text { ciagg Id. 24-25 }\end{array}$ & 24 & 25 & 08.08 .2005 & 82 & 20.08 .2005 & 92 & 28.07 .2005 & 73 & 03.08 .2005 & 78 & 3 \\
\hline
\end{tabular}

Table 2

Schedule data adjusted according to the baseline term after implementation of time buffers

\begin{tabular}{|c|c|c|c|c|c|c|}
\hline id. & Nazwa zadania & Cz. trw. & Rozpoczęcie & Zakończenie & Następniki & $\begin{array}{c}\text { Calkowity } \\
\text { zapas }\end{array}$ \\
\hline 1 & - Budowa stacji metra A19 Marymont w Warszawie - roboty ziemne /fragment harmonogramu/ & $67 \mathrm{dn}$ & śro, 05-05-04 & czw, 05-07-21 & & $0 \mathrm{dn}$ \\
\hline 2 & MOBILIZACJA I PRZYGOTOWANIE SPRZĘTU & $9 \mathrm{dn}$ & śro, 05-05-04 & pia, 05-05-13 & 3ZR-9 dn;4 & $0 \mathrm{dn}$ \\
\hline 3 & PRZYGOTOWANIE FRONTU ROBÓT & $4 \mathrm{dn}$ & wto, 05-05-10 & pia, 05-05-13 & 4 & $0 \mathrm{dn}$ \\
\hline 4 & WYKONANIE ŚCIAN SZCZELINOWYCH - SEKCJE $11-18$ i $37-44$ & $6 \mathrm{dn}$ & sob, 05-05-14 & pią, 05-05-20 & 5 & $0 \mathrm{dn}$ \\
\hline 5 & WYKONANIE ŚCIAN SZCZELINOWYCH- SEKCJE 19-26 i 31-36 & $5 \mathrm{dn}$ & sob, 05-05-21 & piq, 05-05-27 & 26 & $0 \mathrm{dn}$ \\
\hline 6 & WYKONANIE PALI ŚCIANKI BERLIŃSKIEJ & $3 \mathrm{dn}$ & sob, 05-06-11 & wto, 05-06-14 & 7ZR-1 dzień & $0 \mathrm{dn}$ \\
\hline 7 & WYKONANE WYKOPU WSTĘPNEGO SEKCJE 5A I $5 B$ & $3 \mathrm{dn}$ & wto, 05-06-14 & $c z w, 05-06-16$ & 8ZR-2 dn & $0 \mathrm{dn}$ \\
\hline 8 & SKUCIE ŚCIAN SZCZELINOWYCH ORAZ USZCZELNIENIE POLACVZENIA ZE STROPEM ZEWNETRZNYMM- SEKCJE $18-25$ i $32-37$ & $3 \mathrm{dn}$ & śro, 05-06-15 & pią, 05-06-17 & 9ZR-1 dzień & $0 \mathrm{dn}$ \\
\hline 9 & SZALOWANIE SEKCJI 5A & $3 \mathrm{dn}$ & pia, 05-06-17 & pon, 05-06-20 & 27 & $0 \mathrm{dn}$ \\
\hline 10 & ZBROJENIE I BETONOWANIE SEKCJI 5A & $3 \mathrm{dn}$ & pia, 05-06-24 & pon, 05-06-27 & 12ZR+1 dzień & $0 \mathrm{dn}$ \\
\hline 11 & SZALOWANIE SEKCJI 5B & $3 \mathrm{dn}$ & pon, 05-06-27 & śro, 05-06-29 & 13 & $0 \mathrm{dn}$ \\
\hline 12 & ZBROJENIE I BETONOWANIE SEKCJI 5B & $3 \mathrm{dn}$ & śro, 05-06-29 & pia, 05-07-01 & 14 & $0 \mathrm{dn}$ \\
\hline 13 & SZALOWANIE PRZEWYŻSZENIA SEKCJI 5A & $3 \mathrm{dn}$ & $c z w, 05-06-30$ & sob, 05-07-02 & 28 & $0 \mathrm{dn}$ \\
\hline 14 & ZBROJENIE I BETOWNOWANIE PRZEWYŻ̇ZZENIA SEKCJI 5 A & $3 \mathrm{dn}$ & sob, 05-07-02 & wto, 05-07-05 & 29 & $0 \mathrm{dn}$ \\
\hline 15 & WYKONANIE ŚCIAN SZCZELINOWYCH- SEKCJE $27-30$ i $58-59$ & $3 \mathrm{dn}$ & śro, 05-06-08 & pią, 05-06-10 & 16 & $0 \mathrm{dn}$ \\
\hline 16 & WYKONANIE ŚCLAN SZCZELINOWYCH- SEKCJE 8-10 i $45-47$ & $4 \mathrm{dn}$ & sob, 05-06-11 & śro, 05-06-15 & 19;17ZR-3 dn & $0 \mathrm{dn}$ \\
\hline 17 & WYKONANIE PALI ŚCIANKI BERLIŃSKIEJ & $4 \mathrm{dn}$ & pon, 05-06-13 & $c z w, 05-06-16$ & 18 & $0 \mathrm{dn}$ \\
\hline 18 & TYMCZASOWE PRZEKOZZENIE KABLI ENERGETYCZNYCH I TRAKCYJNYCH - WIAZKA 2 & $3 \mathrm{dn}$ & pia, 05-06-17 & pon, 05-06-20 & 19ZR-4 dn & $0 \mathrm{dn}$ \\
\hline 19 & WYKONANIE ŚCIAN SZCZELINOWYCH- SEKCJE $1-7$ i $48-57$ & $6 \mathrm{dn}$ & $c z w, 05-06-16$ & śro, 05-06-22 & 20ZR-3 dn & $0 \mathrm{dn}$ \\
\hline 20 & WYKONANE PALI ŚCIANKI BERLIŃSKIEJ & $5 \mathrm{dn}$ & pon, 05-06-20 & pia, 05-06-24 & $21 Z R-3 d n$ & $0 \mathrm{dn}$ \\
\hline 21 & WYKONANE WYKOPU WSTĘPNEGO SEKCJE 1, 2A, 2 B & $6 \mathrm{dn}$ & śro, 05-06-22 & wto, 05-06-28 & $22 Z R-5 d n$ & $0 \mathrm{dn}$ \\
\hline 22 & SKUCIE ŚCIAN SZCZELINOWYCH ORAZ USZCZELNIENIE POLACZENIA ZE STROPEM ZEWNETRZNYM- SEKCJE 1-8 $147-57$ & $7 \mathrm{dn}$ & $c z w, 05-06-23$ & $c z w, 05-06-30$ & 30 & $0 \mathrm{dn}$ \\
\hline 23 & SZALOWANIE SEKCJI 1 & $3 \mathrm{dn}$ & $c z w, 05-07-07$ & sob, 05-07-09 & 31 & $0 \mathrm{dn}$ \\
\hline 24 & ZBROJENIE I BETONOWANIE SEKCJI 1 & $3 \mathrm{dn}$ & wto, 05-07-12 & $c z w, 05-07-14$ & 25 & $0 \mathrm{dn}$ \\
\hline 25 & ZBROJENIE I BETONOWANIE SEKCJI $2 \mathrm{~B}$ & $3 \mathrm{dn}$ & piq, 05-07-15 & pon, 05-07-18 & 32 & $0 \mathrm{dn}$ \\
\hline 26 & BRK1 & $9 \mathrm{dn}$ & sob, 05-05-28 & wto, 05-06-07 & 15;6ZR-1 dzień & $0 \mathrm{dn}$ \\
\hline 27 & BRK2 & $5 \mathrm{dn}$ & wto, 05-06-21 & sob, 05-06-25 & 10ZR-2 dn;11 & $0 \mathrm{dn}$ \\
\hline 28 & $B Z 1$ & $3 \mathrm{dn}$ & pon, 05-07-04 & śro, 05-07-06 & 23 & $0 \mathrm{dn}$ \\
\hline 29 & BZ2 & $5 \mathrm{dn}$ & śro, 05-07-06 & pon, 05-07-11 & 24 & $0 \mathrm{dn}$ \\
\hline 30 & BWP1 & $10 \mathrm{dn}$ & pia, 05-07-01 & wto, 05-07-12 & $23 Z R-5 d n$ & $0 \mathrm{dn}$ \\
\hline 31 & BWP2 & $2 d n$ & pon, 05-07-11 & wto, 05-07-12 & 24ZR-1 dzień & $0 \mathrm{dn}$ \\
\hline 32 & $\mathrm{BP}$ & $3 \mathrm{dn}$ & wto, 05-07-19 & czw, 05-07-21 & & $0 \mathrm{dn}$ \\
\hline
\end{tabular}




\section{REFERENCES}

1 Chatfield C., Johnson T., Microsoft Office Project 2007 Step by step [in Polish], RM, Warszawa, 2008

2 Goldratt E. M., Critical Chain, The North River Press 1997 P.O. Box 567.

3 Leśniak A., Plebankiewicz E., Zima K. 2012 Design and build procurement system - contractor selection. Archives of Civil Engineering. Volume LVIII, Issue 4, Pages 463-476.

4 Połoński M. 2010, How to calculate dates and slack time in PDM diagram with different relationship types between tasks [in Polish] Scientific Review Engineering and Environmental Sciences 2 (48) p. $60-74$.

5 Połoński M, Pruszyński K., 2008, The time buffers location and critical chain concepts in civil engineering network schedule. Part I. Theoretical background. [in Polish] Przegląd Budowlany 2008, no. 2, p. 45-49.

6 Połoński M, Pruszyński K. 2008, The time buffers location and critical chain concepts in civil engineering network schedule. Part II. Practical application [in Polish]. Przegląd Budowlany 2008, no. 3 , p. $55-62$.

7 Skorupka D. 2005 The method of identification and quantification of construction project risk, Archives of Civil Engineering. Volume LI, Issue 4, Pages 647-662.

8 Wilczewski S., Ms Project 2007 I Ms Project Server 2007. Successful project management [in Polish] Efektywne zarządzanie projektami, Wyd. Helion, Gliwice 2007. 